\title{
Home-prepared soymilk: Potential to alleviate protein- energy malnutrition in low-income rural communities in South Africa?
}

Authors:

Sara S. Duvenage ${ }^{1}$

Wilna H. Oldewage-Theron ${ }^{1}$

Abdulkadir A. Egal ${ }^{1}$

Gabriel N. Medoua ${ }^{1,2}$

\section{Affiliations:}

${ }^{1}$ Centre of Sustainable

Livelihoods, Vaal University

of Technology, South Africa

${ }^{2}$ Centre for Food and

Nutrition Research, IMPM

Cameroon

Correspondence to:

Sara Duvenage

Email:

ssduvenage@gmail.com

Postal address:

Private Bag X021,

Vanderbijlpark 1900

South Africa

Dates:

Received: 21 Jan. 2013

Accepted: 23 May 2013

Published: 11 Oct. 2013

How to cite this article: Duvenage, S.S., OldewageTheron, W.H., Egal, A.A. \& Medoua, G.N., 2013,

'Home-prepared soymilk: Potential to alleviate proteinenergy malnutrition in lowincome rural communities in South Africa?', Health SA Gesondheid 18(1), Art. \#721, 7 pages. http://dx.doi. org/10.4102/hsag.v18i1.721

\section{Copyright:}

(C) 2013. The Authors.

Licensee: AOSIS

OpenJournals. This work

is licensed under the

Creative Commons

Attribution License.
Research findings reported pronounced protein and some energy shortfalls for schoolaged children and female caregivers in rural communities in Qwa-Qwa, South Africa. The household gardening project was expanded to include soy cultivation. Subsequently, a process was developed for home-preparation of soymilk to support macronutrient consumption. The limited explorative experimental approach included chemical analysis for total protein (Kjeldahl digestion, spectrophotometric determination), total carbohydrate (Anthone method) and total lipid content (extraction, Gravimetric method, separation). Total energy content was calculated. All results were benchmarked against equivalents. Duplicate analysis of samples, respectively prepared from 1:2 $(n=6)$ and 1:4 $(n=4)$ volume ratios of rehydrated minced soybeans : water for cooking of soy mash, indicated statistically-significant differences for reported nutrients $(p \leq 0.05)$. Comparison between sourced commercial soymilk products for drinking indicated no statistical differences $(p>0.05)$. Although statistically-significant shortfalls were indicated for nearly all such values for home-prepared soymilk (1:4 ratio) against industrial 'SoyCow' soymilk and values reported in the South African database for standardised nutrient composition of food $(p \leq 0.05)$, a much-needed contribution will be made to protein (and energy) intake through consumption of the product. More efficient extraction (possibly double mincing of rehydrated soybeans and more efficient pressing of cooked soy mash) should be explored, followed by an intervention study to evaluate the impact of daily consumption of home-prepared soymilk on the nutritional status of children in low-income communities. The development of recipes to promote the inclusion of undissolved fibre from the soymilk extraction process (okara) in dishes prepared at household level, such as bread, is recommended.

Navorsing het beduidende proteïen en minder ernstige energie te korte uitgewys by skoolkinders en vroulike versorgers in plattelandse gemeenskappe in Kwa-Kwa. Die huishoudelike tuinbouprojek is uitgebrei om soja-verbouing in te sluit en 'n proses is ontwikkel vir die tuisbereiding van sojamelk om makronutriënt inname te bevorder. Die beperkte eksperimentele benadering het chemiese analise vir totale proteïen (Kjeldahlvertering, spektro-fotometriese bepaling), totale koolhidraat (Anthonemetode) en totale lipied inhoud (ekstraksie, Gravimetriese metode, skeiding) ingesluit. Totale energie is bereken en alle resultate is met ekwivalente vergelyk. Duplikaatanalise van sojamelkmonsters, onderskeidelik berei van 1:2 $(n=6)$ en 1:4 $(n=4)$ volume verhoudings van gehidreerde gemaalde sojabone : water vir die kook van die sojapulp, het statisties-beduidende verskille uitgewys $(p \leq 0.05)$. Geen statisties-beduidende verskille is gevind in die makronutriëntwaardes van kommersiële sojamelkprodukte wat gedrink kan word nie $(p>0.05)$. Alhoewel statisties-beduidende tekorte vir bykans alle soortgelyke waardes van tuisbereide sojamelk (1:4) teenoor die industrieel bereide 'SoyCow' produk en waardes gerapporteer in die Suid Afrikaanse databasis vir gestandardiseerde nutriëntsamestelling van voedsel $(p \leq 0.05)$ waargeneem is, sal inname van die tuisbereide produk tog 'n belangrike bydrae tot proteïen (en energie) inname kan lewer. Die effektiwiteit van ' $n$ verbeterde nutriëntekstraksie, byvoorbeeld deur 'n dubbel-maalproses en meer effektiewe pers van die gekookte sojapulp, moet ondersoek word. 'n Intervensiestudie om die effek van daaglikse sojamelk inname op die voedingstatus van kinders in lae-inkomste bemeenskappe te meet, word aanbeveel. Verder word aanbeveel dat resepte ontwikkel word om die onopgeloste vesel wat oorbly na die melkmaak proses (okara) in huishoudelike geregte in te sluit, byvoorbeeld in die bereiding van brood.

\section{Introduction}

\section{Problem statement}

Although South Africa (SA) is food secure at a national level, the effects of poverty present strongly as a lack of household food security and are notable specifically in rural areas (Koch 2011). 
Children represent one of the most vulnerable groups and the deterioration of child health, in spite of the implementation of various national nutrition and primary healthcare programmes, is of concern (Bourne et al. 2007; South African Department of Health 2004; United Nations 2012) and needs to be improved. In the short term, malnutrition impacts on the growth, well-being, school attendance and performance of children (Parker \& Tubbs 2012), whilst longer-term consequences based on poor dietary habits manifest as nutrition-related chronic diseases of lifestyle (MacIntyre et al. 2002; Vorster \& Bourne 2008).

\section{Background}

Qwa-Qwa forms part of the south-eastern area of the Thabo Mofutsanyane district, situated in the Free State province of SA. This district, with a population of 766754 as at 2005 , is severely impoverished and $73 \%$ of the inhabitants are living below the poverty line for SA (Punt et al. 2005). The nutritional shortfalls identified in a rural Qwa-Qwa community included protein and energy, with 53\% and $17 \%$ respectively of the primary-school children chronically not meeting $100 \%$ of the estimated average requirement (EAR) for these nutrients for active boys and girls aged nine to 13 years (Oldewage-Theron \& Egal 2010). However, the clinical signs of protein and energy malnutrition (PEM) - oedema, diarrhoea and irritability - were not pronounced from a clinical standpoint.

Subsequently, the project 'Improving household food security in Qwa-Qwa' was implemented from 2008 in order to assess the situation and intervene, if warranted, in three additional communities in the region. The prevalence of PEM, inter alia, was confirmed in female caregivers in these households in food-insecure communities $(n=383)$ (Oldewage-Theron, Duvenage \& Egal 2012), culminating in the launch of several initiatives. These included the establishment and/or expansion of vegetable home gardens to include soy (Glycine max) and the development and target consumer-acceptance testing of a series of recipes containing home-produced soy $(n=75-101)$, including soymilk (Duvenage, OldewageTheron \& Egal 2012).

\section{Trends}

Soybeans are the only plant source providing complete protein (United Soybean Board 2013). Soybeans contain $38 \%$ protein, $30 \%$ carbohydrate and $18 \%$ fat, providing a healthy and affordable food source for these macronutrients (US Department of Agriculture 2012). Simultaneously, a valuable contribution is made to the intake of almost all of the micronutrients that are most compromised in the diets of low-income communities, namely total dietary fibre, calcium, iron, magnesium, zinc and folate (Faber, Witten \& Drimie 2011).

Soymilk is a food commodity that could plausibly be used in various forms on a daily basis by all age groups. For example, drinking as is, flavoured, in tea or coffee or in food preparation, to supplement or to replace the very limited habitual intake of cow's milk by the target population (203 g/day by only $25 \%$ of the respondents) (Oldewage-Theron et al. 2012).

The electric industrial 'SoyCow' food-processing system, promoted by the World Soy Foundation as a valuable tool for combating malnutrition in afflicted areas (World Soy Foundation 2012), consists of a grinder-cooker, steam boiler and a manually-operated press, which delivers about 18.2 litres of soymilk from $1.8 \mathrm{~kg}$ of raw presoaked soybeans and water in approximately 20 minutes (World Soy Foundation n.d.). Value-added products such as tofu and yoghurt can be produced from the soymilk. However, the cost involved in purchasing of a smaller unit with a capacity of 28 litres / hour, is R66 402.00 ( $\$ 7496$ with $\$ 1.00 \approx \mathrm{R} 8.86$ ) excluding taxes, shipping and duties (Pristine Plants India 2013), placing it out of reach financially for these rural communities. A cheaper option for the home-preparation of soymilk was consequently considered.

\section{Contribution to the field}

Different sources of information on soymilk preparation methods were tapped for inspiration, including work by the World Initiative for Soy in Human Health (WISHH) and the traditional Japanese method (boiling of the soy mash followed by hot filtration) (Sweeney n.d.; Wikipedia 2012; WISHH n.d.). The method developed for the home preparation of soymilk acknowledged the (lack of) facilities generally available in the households of the target population, with specific reference to availability of appliances, fuel for extended periods of heating (electricity, gas, benzene, etc.) and household income (Oldewage-Theron et al. 2012). As no electrical appliances were available for grinding, the rehydrated beans could either be minced with a hand machine or coarsely grounded or chopped between two stones before being processed for milk extraction. The aim was to keep the process as affordable, simple and do-able as possible.

\section{Key focus and research objective}

Will the process developed for the home preparation of soymilk make a feasible contribution to the nutrient intake of the target population? Certain questions come to mind:

- Did the soymilk delivered by the home-preparation method produce similar values for macronutrient and energy content to the commercially-prepared equivalents available in SA, the product produced by the industrial 'SoyCow' and the nutrient value for soymilk reported by the Condensed food composition tables for South Africa (CFCTSA) (Wolmarans et al. 2010)?

- Would the contribution made to the macronutrient and energy intake of the target population be such that it would be feasible to launch a project to promote the home preparation of soymilk in these communities?

This article will focus on answering these questions. 


\section{Research method and design Design}

In order to guide further decisions, a limited explorative experimental analysis of the total macronutrient content (protein, carbohydrates and lipids) of home-prepared soymilk was conducted to enable comparison with commerciallyprepared equivalents, 'SoyCow' soymilk and CFCTSA indicators.

\section{Materials}

A batch of mixed genetically-modified soy, similar to the product utilised for the production of soymilk by the industrial 'SoyCow' system, was obtained from the Eden Social Development Foundation, a non-governmental organisation presenting soy-awareness programmes in communities in SA. The soy was stored at ambient temperature in gunny bags in dry hygienic conditions.

\section{Sample preparation}

As the contribution to health was of major concern for these low-income households, no bicarbonate of soda was added during soymilk preparation to enhance softening as nutrient content would be influenced adversely (Shurtleff 2000). Instead, a prolonged soaking period was utilised in order to aid the rehydration of the dry raw soybeans.

To obtain a better understanding of how the macronutrient content differed according to different ratios of rehydrated minced soybeans to water and to adhere to strict financial constraints, only two formulations of home-prepared soymilk, consisting of different ratios of soybeans to water, were included.

After careful removal of all foreign material, the dry soybeans were rinsed to remove dust, covered with ample cold tap water (four cups of water to one cup of soybeans) and left to rehydrate at ambient temperature for 12 hours. All foam was removed at regular intervals. The rehydrated soybeans were then drained, rinsed under running tap water, and minced with a household manual grinder (Bolinder No. 8) to allow its further use for milk production.

Three samples containing a ratio of one part of rehydrated minced soybeans to four parts of tap water/volume and two samples containing a ratio of one part of rehydrated minced soybeans to two parts of tap water/volume, were prepared individually to form a mash. Each sample of mash was simmered carefully for 20 minutes and strained through a double layer of prewashed cheesecloth. The ends of the cloth were wrapped over carefully to cover the remaining solids (okara) in the strainer. A small plate, holding a $5 \mathrm{~kg}$ weight, was placed on top for one hour to aid in the pressing out of all liquids. For the purposes of this study, the okara was discarded. Each soymilk sample was labelled with a threedigit code number to support blind analysis (Bless \& HigsonSmith 1995), cooled and refrigerated at $4{ }^{\circ} \mathrm{C}$ until analysis within 24 hours.

\section{Procedures}

\section{Home-prepared soymilk}

Duplicate analyses were conducted for the macronutrients (total protein, total carbohydrate and total lipid content) of the three 1:4 ratio and two 1:2 ratio home-prepared soymilk samples.

Crude protein content $(\mathrm{N}$ [nitrogen] $\times 6.25)$ was determined by using the Kjeldahl digestion technique followed by spectrophotometric determination of the resulting ammonia, using the method described by Devani et al. (1989).

Total carbohydrates were evaluated by the Anthrone method after hot digestion with $2.5 \mathrm{~N}$-hydrochloric acid (Hedge \& Hofreiter 1962). Moisture and soluble solids were determined by air drying $10 \mathrm{~g}$ of sample in an oven at $105^{\circ} \mathrm{C}$ to a constant weight (Association of Official Analytical Chemists 1997).

Total lipid content was determined by chloroform-methanol extraction followed by application of the Gravimetric method (Bligh \& Dyer 1959). Using a $100 \mathrm{~mL}$ conical flask containing $5 \mathrm{~mL}$ of the sample, $20 \mathrm{~mL}$ methanol $(\mathrm{MeOH})$ and $10 \mathrm{~mL}$ chloroform $\left(\mathrm{CHCl}_{3}\right)$ were added and vortexed for 2 minutes. This procedure was followed by the addition of $10 \mathrm{~mL} \mathrm{CHCl}_{3}$ and vigorous shaking for 2 minutes, then addition of $18 \mathrm{~mL}$ distilled water and vortexing for 2 minutes. The layers were separated by centrifugation for 10 minutes at $2000 \mathrm{rpm}$. The lower layer was transferred to a pear-shaped flask using a Pasteur pipette.

A second extraction was performed with $20 \mathrm{~mL} 10 \%$ (v/v) $\mathrm{MeOH}$ in $\mathrm{CHCl}_{3}$ and vortexing for 2 minutes. After centrifugation, the $\mathrm{CHCl}_{3}$ phase was added to the rest of the extract, followed by air-drying of the samples in a drying oven and cooling of the dried samples in a desiccator. Finally, the samples were weighed and the total lipid content determined by application of the following formula:

Total lipid $(\mathrm{g} / 100 \mathrm{~g}$ wet weight $)=(\mathrm{W} 2-\mathrm{W} 1)^{*} 100 / \mathrm{SW} \quad$ [Eqn 1]

where W2 is the weight of the tube and dried extract (g), W1 is the weight of an empty dried tube $(\mathrm{g})$ and SW is the weight of the food sample assayed $(\mathrm{g})$.

Energy content was calculated from the macronutrient content analysed for each sample, unless provided by a source, using the conversion factors of $9 \mathrm{kcal} / \mathrm{g}$ for fat, $4 \mathrm{kcal} / \mathrm{g}$ for protein and $4 \mathrm{kcal} / \mathrm{g}$ for carbohydrate (Food and Agricultural Organization of the United Nations 2003). To ensure close comparison without the influence of rounded conversion factors, values of $37.66 \mathrm{~kJ} / \mathrm{g}, 16.74 \mathrm{~kJ} / \mathrm{g}$ and $16.74 \mathrm{~kJ} / \mathrm{g}$ were used for fat, protein and carbohydrate respectively.

\section{'SoyCow' soymilk}

The macronutrient content of soymilk, as produced through the industrial 'SoyCow' process, was obtained through electronic inquiry from a company specialising in the processing of 
soya into an aqueous solution (Eden Social Development Foundation 2012, as obtained from Malnutrition Matters).

\section{Commercially-available soymilk}

A survey was conducted at all local major grocery chain stores in order to identify the different commercial soymilk products that are suitable for drinking and to capture data recording values for macronutrient and energy content from the packaging material.

\section{Data analysis}

All experimental results for macronutrient content were reported in terms of $\mathrm{g} / 100 \mathrm{~g}$, and as $\mathrm{kJ} / 100 \mathrm{~g}$ for energy content. Due to inconsistency in the units applied by industry in the reporting of values, data was converted for $100 \mathrm{~g}$ units when applicable, to support comparison. As comparison rates for volume to weight were not available for soymilk, fresh milk $\left(59^{\circ} \mathrm{F}, 15^{\circ} \mathrm{C}\right)$ was used as a reference (Convert-me. com 2005).

Excel 2003 was used to calculate mean $( \pm$ SD) for the respective data sets, as well as $t$-tests to indicate differences between the sets of different soymilk commodities $(N=4)$ (Porkess 2005).

\section{Results and discussion}

\section{Macronutrient and energy content of home- prepared soymilk}

The mean $( \pm \mathrm{SD})$ content for total fat, total carbohydrate, total protein and calculated energy of the respective homeprepared soymilk preparations are reported in Table 1.

As expected, the 1:2 ratio (volume rehydrated minced soybeans : water, for cooking of soy mash) delivered a product that was significantly more nutrient dense in all regards (Table 1) ( $p \leq 0.05)$, but was also less cost effective, especially on a daily basis, and therefore less sustainable in the long run for these low-income households. At this stage, however, an acceptance of the sensory attributes of the soymilk prepared according to the 1:4 ratio was already confirmed for the target group, with an increasing rate of self-preparation over time (Duvenage et al. 2012). Therefore, only soymilk prepared according to the 1:4 ratio was applied for further comparison.

\section{Macronutrient and energy content of commercial soymilk}

Only four different brands of commercial soymilk products that are suitable for drinking were available in the outlets of local major retailers, most offering a choice of two or more brands of the soymilk products carried. For convenience in comparison, the products were grouped into different categories. It should be noted that differences in commercial production processes and ingredients were not accounted for; only nutrient content as recorded on packaging material. The mean $( \pm$ SD) findings are reported in Table 2 .

$T$-tests revealed no statistically-significant differences between the respective commercial soymilk categories for any of the macronutrients $(p \leq 0.05)$, implying an approximately equal contribution to macronutrient intake by any of the categories when consumed in equal quantities. It therefore follows that commercial regular soymilk, the product most frequently available for purchase in the outlets, may be used for the purposes of further comparison.

However, it is of interest that the mean carbohydrate content of flavoured soymilk and the alternative soymilk drinks is seemingly higher than for regular soymilk, which results increases in the respective energy values. A further point of interest is that the kilojoule content of low-fat soymilk is higher than that of regular soymilk, mainly as a result of higher mean carbohydrate content. A lack of standardisation of information recorded on the packaging material became apparent, complicating drawing of relevant comparisons between products and therefore also interpretation by consumers.

\section{Comparison of macronutrient and energy content}

The macronutrient and energy content of home-prepared and commercial soymilk and soymilk derived by the 'SoyCow' process (mean $\pm \mathrm{SD}$ ), as well as the values indicated by the

TABLE 1: Macronutrient and energy content of home-prepared soymilk (mean \pm SD).

\begin{tabular}{|c|c|c|c|c|c|c|}
\hline Ratio $^{a}$ & Moisture (g/100 g) & Soluble solids (g/100 g) & Total fat $(\mathrm{g} / 100 \mathrm{~g})$ & $\begin{array}{l}\text { Total carbohydrate } \\
\text { (g/100 g) }\end{array}$ & Total protein $(\mathrm{g} / 100 \mathrm{~g})$ & Energy $(\mathrm{kJ} / 100 \mathrm{~g})$ \\
\hline $1: 4(n=6)$ & $82.15 \pm 33.96 \dagger$ & $5.28 \pm 0.18 \%$ & $0.85 \pm 0.1 \S$ & $1.52 \pm 0.099$ & $1.45 \pm 0.05 \dagger \dagger$ & $81.62+3.18+t$ \\
\hline $1: 2(n=4)$ & $74.29 \pm 39.29 \dagger$ & $7.31 \pm 1.85 \ddagger$ & $1.27 \pm 0.07 \S$ & $2.51 \pm 0.079$ & $2.31 \pm 0.03 \dagger \dagger$ & $128.2+2.28+t$ \\
\hline
\end{tabular}

Source: Authors' own construction

a, Volume ratio rehydrated minced soybeans: water, for cooking of soy mash

Means in the same column with similar superscripts are statistically different $(p \leq 0.05)$ as reported by $t$-tests (equal variances not assumed).

$\dagger, 1.7995 \mathrm{E}-09 ;+1.8 \mathrm{E}-09 ; \S, 6.02 \mathrm{E}-05 ; \uparrow, 1.03479 \mathrm{E}-07 ; \dagger+5.54 \mathrm{E}-10 ; \$+4.85662 \mathrm{E}-09$.

TABLE 2: Macronutrient and energy content of commercial soymilk suitable for drinking (mean \pm SD).

\begin{tabular}{|c|c|c|c|c|}
\hline Commercial soymilk & Total fat $(\mathrm{g} / 100 \mathrm{~g})$ & Total carbohydrate $(\mathrm{g} / 100 \mathrm{~g})$ & Total protein $(\mathrm{g} / 100 \mathrm{~g})$ & Energy $(\mathrm{kJ} / 100 \mathrm{~g})$ \\
\hline Regular soymilk $(n=5)$ & $1.62 \pm 0.37$ & $2.11 \pm 1.13$ & $2.74 \pm 0.48$ & $147.17 \pm 26.68$ \\
\hline Low-fat soymilk ( $n=2$ ) & $1.55 \pm 0.54$ & $3.87 \pm 2.74$ & $2.47 \pm 0.62$ & $164.15 \pm 76.61$ \\
\hline Flavoured soymilk $(n=2)$ & $1.69 \pm 0.07$ & $7.97 \pm 2.12$ & $3.05 \pm 0.21$ & $242.37 \pm 42.6$ \\
\hline Alternative soymilk drinks ${ }^{\mathrm{a}}(n=4)$ & $1.73 \pm 0.63$ & $5.27 \pm 2.26^{b}$ & $2.37 \pm 0.61^{\mathrm{b}}$ & $188.41 \pm 61.04$ \\
\hline
\end{tabular}

Source: Authors' own construction

Means \pm SD calculated from data sourced from commercially available products.

a, Combined group: products indicated as 'soy drinks', 'milk alternatives', or 'soy shakes'.

b, As calculated from available data. 
CFCTSA (Wolmarans et al. 2010) for soymilk, are reported in Table 3.

Statistically-significant differences $(p \leq 0.05)$ were reported for the total fat content of home-prepared soymilk (1:4 ratio) against commercial regular soymilk and the CFCTSA and consequently also for the energy content of these commodities ( $1 \mathrm{~g}$ fat $\approx 37.66 \mathrm{~kJ}$ or $9 \mathrm{kcal}$ ). The uncommonly-high energy content of industrial 'SoyCow' soymilk, indicated as being different in a statistically-significant manner from all the other soymilk commodities, could not be explained by its macronutrient content as reported by the source.

Likewise, statistically-significant differences were indicated in the total carbohydrate content of home-prepared soymilk (1:4 ratio) as compared against industrial 'SoyCow' soymilk and the CFCTSA, as well as in its protein content as compared against commercial regular soymilk (all commercial soymilk categories as based on results in Table 2) and the CFCTSA.

In overview, it is notable that statistically-significant differences between home-prepared soymilk and the CFCTSA were indicated for all macronutrients as well as for energy, indicating a shortfall for these nutrients against the values recommended for use in South Africa.

\section{Ethical considerations}

Approval for the 'Improving household food security in Qwa-Qwa' project, embedding the initiative being reported in this article, was obtained from the Medical Ethics Committee for Research on Human Beings of the University of the Witwatersrand (M080931).

\section{Potential hazards and benefits}

Work conducted for the purpose of this article involved no direct interaction with target respondents suffering from PEM in low-income rural communities and therefore included no risk to them. However, the findings derived from this study could benefit them, and others, in the selfsustainable alleviation of PEM.

\section{Informed consent and data protection}

Data sourced for the macronutrient and energy content of the commercial soymilk products were generally available in the marketplace and consequently no arrangements were required regarding consent or data protection.

\section{Validity and reliability Reliability}

At least two samples of each home-prepared soymilk formulation, independently prepared, were submitted for analysis. In addition, each experimental sample was subjected to duplicate analysis. Analysis was conducted by an accredited experienced practitioner. In further support of reliability, an analytical reference material (MUVA-M-0110, UHT milk) was used to track method performance and variability over time. The reference values were $3.542 \pm$ $0.008 \mathrm{~g} / 100 \mathrm{~g}$ for fat, $3.356 \pm 0.012 \mathrm{~g} / 100 \mathrm{~g}$ for protein (Kjeldahl), $4.678 \pm 0.044 \mathrm{~g} / 100 \mathrm{~g}$ for carbohydrates and $12.35 \pm 0.07 \mathrm{~g} / 100 \mathrm{~g}$ for dry matter. The recovery percentage ranged from $99.3 \%$ to $101 \%$ and the coefficient of variation ranged between $1.1 \%$ and $1.6 \%$.

\section{Validity milk, soy). \\ Conclusion and practical implications}

Internationally-accepted indicators and methods wereapplied for analysis to support comparability between experimental findings and against existing relevant commercial data sets. Experimental findings were also benchmarked against an established norm, namely the CFCTSA (Group 6, Code 2737,

To determine whether the self-prepared soymilk could make a feasible contribution to the macronutrient and energy intake of low-income households in rural communities, various comparisons involving industrial and commercial products and the South African database for standardised nutrient composition of food (CFCTSA) were drawn.

Of the two sets of home-prepared soymilk, 1:2 and 1:4 volume ratios of rehydrated minced soybeans: water respectively for the cooking of soy mash, the latter was already established in soymilk-preparation practices by the target communities. Although this ratio delivered a product that was lower in macronutrient and energy content, the lower ratio of soybeans will be more sustainable in the long run, calculated against the quantities of soy produced in the home gardens.

TABLE 3: Comparison of macronutrient and energy content of soymilk commodities (mean \pm SD).

\begin{tabular}{|c|c|c|c|c|}
\hline \multirow[t]{2}{*}{ Soymilk commodities } & \multicolumn{3}{|c|}{ Macronutrients $(\mathrm{g} / 100 \mathrm{~g})$} & \multirow[t]{2}{*}{ Energy (kJ/100g) } \\
\hline & Total fat & Total carbohydrate & Total protein & \\
\hline Home-prepared soymilk (1:4 ratio) & $0.85 \pm 0.1 \dagger, \ddagger$ & $1.52 \pm 0.09 \S, 9$ & $1.45 \pm 0.05 \dagger \uparrow,+\hbar$ & $81.62 \pm 3.18 \S \S, 99,+\dagger \dagger$ \\
\hline Commercial regular soymilk ${ }^{\mathrm{b}}$ & $1.62 \pm 0.37 \dagger$ & $2.11 \pm 1.13$ & $2.74 \pm 0.48 \dagger \dagger$ & $147.17 \pm 26.66 \S \S, 4+4$ \\
\hline Industrial 'SoyCow' soymilkc & $1.4-1.6$ & $2 \S$ & $3.4-4$ & $1849 \uparrow, 木+4, \S \S \S$ \\
\hline CFCTSA $^{d}$ & $1.9 \ddagger$ & $1.8 \mathrm{e}, \boldsymbol{\Phi}$ & $2.8+t$ & $149 \dagger \dagger \dagger, \S \S \S$ \\
\hline
\end{tabular}

a, From Table 1. Values are given as means \pm s.d. $(n=6)$.

$\checkmark$, From Table 2. Values are given as means \pm s.d. $(n=5)$

, Supplied by Eden Social Development Foundation 2012, as obtained from Malnutrition Matters. Values are given as means.

, CFCTSA, Condensed Food Composition Tables for South Africa, 2010. (Group 6, Code 2737, Milk, soy.) Values are given as means.

e, Total carbohydrate calculated from values indicated for available carbohydrate $(\mathrm{g})$ and total dietary fibre $(\mathrm{g})$.

$P$-values that are statistically different $(p \leq 0.05)$ as reported by $t$-tests (equal variances not assumed), were indicated by similar symbols:

$\dagger,=0.0082 ;+=9.9578 \mathrm{E}-05 ; \S,=5.71935 \mathrm{E}-05 ; \uparrow,=0.0176 ; \dagger,=0.0036 ;+,=0.0006 ; \S \S,=0.0067 ; \uparrow \uparrow,=6.2256 \mathrm{E}-09 ; \dagger+,=1.54167 \mathrm{E}-09 ;+t+,=0.0251 ; \S \S \S,=0.0002$. 
The more concentrated product (1:2 ratio) is probably more suitable for the preparation of richer products, such as tofu made from soymilk curd, with which the target communities were unfamiliar. This option will be kept in mind for further training in the target community.

The significant shortfalls in all macronutrients, as well as energy, reported for home-prepared soymilk (1:4 ratio) against equivalent commercial commodities and the CFCTSA could imply that industrial processes for extraction are more effective and accordingly deliver products of higher macronutrient density.

The average dietary intake of protein by the target community $(n=383)$ were mostly obtained from the consumption of cooked chicken (fifth on the list of top twenty foods consumed in highest quantities at $123 \pm 80 \mathrm{~g} /$ capita/day by $30 \%$ of respondents) and $36 \mathrm{~g}$ fresh full cream milk/capita/ day (sixth on the list at $129 \pm 109 \mathrm{~g} /$ capita/day for $28 \%$ of the respondents). Overall shortfalls in daily mean intakes, as reported against EAR, were reported for protein $(65 \%$ of respondents), for carbohydrates (38\%), for dietary fibre (95\%), and for energy (93\%) (Oldewage-Theron et al. 2012).

To derive benefit from soy consumption, a minimum intake of at least $15 \mathrm{~g}$ soy protein/capita/day is recommended (Pelembe 2009). As mature soybeans contain approximately 38\% protein (US Department of Agriculture 2012), in theory, the equivalent of approximately $40 \mathrm{~g}$ of soybeans needs to be consumed/capita/day, implying that the equivalent of $240 \mathrm{~g}$ (1 cup) of dry soybeans (2 cups of firmly-packed, rehydrated, minced soybeans) needs to be prepared for a household of six people (Duvenage, Oldewage-Theron \& Egal 2011). With the consumption of a serving of approximately $125 \mathrm{~mL}$ (130 g) soymilk/capita/day included as part of the two servings of soy-containing dishes to be consumed/capita/ day, or a single serving of $260 \mathrm{~g}(250 \mathrm{~mL})$ soymilk/capita/ day, a notable contribution can be made to protein and energy consumption at the household level. It is therefore worthwhile to promote this project.

As the PAN1454R cultivar is a quick-maturing soybean suitable for cooler regions with a restricted growing season, it was chosen for cultivation by the participating Qwa-Qwa communities. A protein content of $39.8 \%-44.48 \%$ and a fat content of $19.17 \%-18.83 \%$ (respectively for colder and average temperatures) is typical of this cultivar, depending on conditions and crop management (Erasmus \& de Beer $2011 / 2012$ ), providing a more satisfactory point of departure for the provision of protein and energy to the households in this area.

The implication is that the impact of a lack of foodpurchasing power, identified as the main contributor to food insecurity in South Africa (Koch 2011), will be less disruptive to the provision of essential protein and energy to vulnerable groups such as low-income rural communities. Thereby, the alleviation of PEM could be supported at household level in a more sustainable level.

\section{Limitations of the study}

Although the limited number of samples influences broader generalisation, the derived findings supported the explorative nature of the study. A better understanding was derived regarding the contribution that the consumption of home-prepared soymilk could make to protein and energy intake, albeit less than commercial and industrial products. The direction of action to be taken was suggested.

\section{Recommendations}

A four-pronged approach is recommended for further studies:

1. Development of a cost-efficient manual tool to aid the separation of the milk from the soy mash for enhanced extraction efficiency during home-preparation of soymilk.

2. Inclusion of undissolved fibre from the soymilk extraction process (okara) as an ingredient in dishes such as bread and rusks, as the less effective home-extraction process suggests a higher level of nutrients in the resultant okara.

3. Consideration of whether the seed variants available for commercial soy cultivation in South Africa hold the best options for household cultivation and nutrition.

4. An intervention study to evaluate the impact of daily consumption of soymilk on the nutritional status of children in the communities forming part of this study.

\section{Acknowledgements}

The following contributions are recognised with appreciation: (1) South Africa-Netherlands Research Programme on Alternatives in Development (SANPAD) for funding (Grant number 09/18); and (2) Centre of Sustainable Livelihoods, Vaal University of Technology, for creating the opportunity for the study.

\section{Competing interests}

The authors declare that they have no financial or personal relationship(s) which may have inappropriately influenced them in writing this article.

\section{Authors' contributions}

W.H.O-T. (Vaal University of Technology) was the project leader. S.S.D. (Vaal University of Technology) compiled the home-preparation method, prepared the samples for analysis and gathered data for commercial and other products for comparison. G.N.M. (Vaal University of Technology) planned and performed the chemical analysis, A.A.E. (Vaal University of Technology) assisted with statistical analysis and reporting and S.S.D. compiled the article.

\section{References}

Association of Official Analytical Chemists, 1997, Official methods of analysis, 16th edn., AOAC, Washington, DC.

Bless, C. \& Higson-Smith, C., 1995, Fundamentals of social research methods: An African perspective, Juta, Cape Town.

Bligh, E.G. \& Dyer, W.J., 1959, 'A rapid method of total lipid extraction and purification', Canadian Journal of Biochemistry and Physiology 37(8), 911-917. http://dx.doi. org/10.1139/059-099, PMid:13671378 
Bourne, L.T., Hendricks, M.K., Marais, D. \& Eley, B., 2007, 'Addressing malnutrition in young children in South Africa. Setting the national context for paediatric foodbased dietary guidelines', Maternal \& Child Nutrition 3(4), 230-238. http://dx.doi. based dietary guidelines', Maternal \& Child Nutrition 3(4),
org/10.1111/j.1740-8709.2007.00108.x, PMid:17824851

Convert-me.com, 2005, Weight to volume conversion online, viewed 07 February 2012, from http://www.convert-me.com/en/weight2volume

Devani, M.B., Shishoo, C.J., Shah, A.S. \& Suhgka, B.N., 1989, 'Spectrophotometric method for microdetermination of nitrogen in kjeldahl digest', Journal of the Association of Official Analytical Chemists 72(4), 953-956.

Duvenage, S.S., Oldewage-Theron, W.H. \& Egal, A.A., 2011, Healthy cooking with soy, Printcare, Vanderbijlpark Duvenage, S.S., Oldewage-Theron, W.H. \& Egal, A.A., 2012, 'Acceptance of home-
prepared soy dishes in low-income rural Qwa-Qwa communities', Internationa Journal of Home Economics 5(2), 151-166. PMid:21920123

Eden Social Development Foundation, 2012, e-mail, 11 May, eden@intekom.co.za. Eden Social Development Foundation obtained information on nutrient content of 'SoyCow' produced soymilk from Malnutrition Matters.

Erasmus, J.L. \& de Beer, A.S., 2011/2012, Sojaboon kultivaraanbevelings/Soybean cultivar recommendations 2011/2012, Brochure, Agricultural Research CouncilGrain Crops Institute, Potchefstroom.

Faber, M., Witten, C. \& Drimie, S., 2011, 'Community-based agricultural interventions in the context of food and nutrition security in South Africa', South African Journal of Clinical Nutrition24(1), 21-30.

Food and Agricultural Organization of the United Nations, 2003, 'Food energy: Methods of analysis and conversion factors', FAO Food and Nutrition Paper 77 Food and Agricultural Organization, Rome, viewed 26 April 2013, from http:// www.fao.org/docrep/006/y5022e/y5022e00.htm

Hedge, J.E. \& Hofreiter, B.T., 1962, 'Estimation of carbohydrate', in R.L. Whistler \& J.N. BeMiller (eds.), Carbohydrate chemistry, pp. 17-22, Academic, New York.

Koch, J., 2011, 'The food security policy context in South Africa', International Policy Centre for Inclusive Growth, United Nations Development Programme, viewed 07 December 2011, from http://www.ipc-undp.org/pub/IPCCountryStudy21.pdf

MacIntyre, U.E., Kruger, H.S., Venter, C.S. \& Vorster, H.H., 2002, 'Dietary intakes of an African population in different stages of transition in the North-West Province South Africa: The THUSA study', Nutrition Research 22(3), 239-256. http://dx.doi. org/10.1016/S0271-5317(01)00392-X

Oldewage-Theron, W.H. \& Egal, A.A., 2010, 'Nutrition knowledge and nutritional status of primary school children in QwaQwa', South African Journal of Clinical Nutrition 23(3), 149-154.

Oldewage-Theron, W.H., Duvenage, S.S. \& Egal, A.A., 2012, 'Situation analysis as indicator of food insecurity in low-income rural communities', Journal of Family Ecology and Consumer Sciences 40, 38-58.

Parker, S. \& Tubbs, C., 2012, 'Aggregate economic shocks during middle childhood' in M. Lundberg \& A. Wuermli (eds.), Children and youth in crisis: Protecting and promoting human development in times of economic shocks, pp. 149-187, The World Bank, Washington DC, viewed 18 June 2013, from http://web.Worldbank. org/WBSITE/EXTERNAL/TOPICS/EXTSOCIALPROTECTION/0,,contentMDK:232198
78 pagePK:210058 piPK:210062 theSitePK:282637 isCURL:Y,00.html
Pelembe, L., 2009, Soy on your table is health on your table: Soy recipes booklet, World Initiative for Soy in Human Health, Maputo.

Porkess, R., 2005, Collins internet-linked dictionary of statistics, 2nd edn., Collins, Glasgow. PMCid:PMC1774360

Pristine Plants India, 2013, 'Innovative answers to your need', viewed 19 January 2013, from http://ppi.co.in/pages/cost-benefits-analysis3.html

Punt, C., Pauw, K., Van Schoor, M., Nyhodo, B., McDonald, S., Chant, L. et al., 2005, 'PROVIDE project: A profile of the Free State Province: Demographics, poverty, inequality and unemployment', Background Paper 2005:1(4), viewed 31 May 2011, from www.elsenberg.com/provide/documents/BP2005_1_4\%20 Demographics\%20FS.pdf

Shurtleff, W., 2000, 'Tofu and Soymilk Production: A Craft and Technical Manual', Soyfoods Production Series: No 2, 3rd edn., Soyinfo Center, viewed 30 April 2013, from http://www.SoyinfoCenter.com/books-technical.php

South African Department of Health, 2004, Integrated nutrition programme: A foundation for life, brochure, Department of Health, Pretoria.

Sweeney, N., n.d., 'Making soya milk and tofu by self sufficiency guru Nev Sweeney', viewed 01 December 2012, from http://www.selfsufficientish.com/soyamilk.htm

United Nations, 2012, Africa human development report 2012: Towards a food secure future, viewed 22 May 2012, from http://reliefweb.int/node/496687

United Soybean Board, United States Department of Agriculture, 2013, 'Soy nutritional content', viewed 29 April 2013, from http://www.soyconnection.com/ soy_foods/nutritional_composition.php

U.S. Department of Agriculture, Agricultural Research Service, 2012, 'USDA National Nutrient Database for Standard Reference, Release 25', viewed 25 April 2013, from http://www.ars.usda.gov/ba/bhnrc/ndl

Vorster, H.H. \& Bourne, L., 2008, 'The nutrition transition in South Africa', in N.P. Steyn $\&$ N. Temple (eds.), Community nutrition textbook for South Africa: A rights-based approach, pp. 233-250, Medical Research Council, Cape Town.

Wikipedia, 2012, 'Soy milk', viewed 23 November 2012, from http://en.wikipedia. org/wiki/Soy_milk

Wolmarans, P., Danster, N., Dalton, A., Rossouw, K. \& Schönfeldt, H., 2010, Condensed food composition tables for South Africa, Medical Research Council, Cape Town. PMid:20833235

World Initiative for Soy in Human Health (WISHH), n.d., 'Composition of soy', viewed 06 September 2011, from http://www.wishh.org/aboutsoy/composition.html

World Initiative for Soy in Human Health (WISHH), n.d., Improving health through soy: A basic training manual, United States Department of Agriculture, St. Louis, MO.

World Soy Foundation, 2012, 'World Soy Foundation works to grow SoyCow herd to fight hunger', viewed 25 April 2013, from http://www.worldsoyfoundation.org/ news\&events/news_releases/12mar15.html

World Soy Foundation, n.d., 'SoyCow \& VitaGoat', viewed 31 January 2012, from http://www.worldsoyfoundation.org/whysoy/soycow.html 